\title{
Pengembangan Lembar Kerja Siswa (LKS) Ilustratif Bermuatan Pendidikan Karakter Pada Pembelajaran Matematika SDN 01 Rejang Lebong
}

\author{
Zahratul Fitria, Syaripah \\ Institut Agama Islam Negeri Curup, Indonesia \\ zahratulfitria1223@gmail.com, syana1401@gmail.com
}

\begin{abstract}
The background of this research was a phenomenon in the educational process where the teaching materials used were not optimal, so a development was needed. In this case, the teaching materials were Students Worksheets (LKS) used at SDN 01 Rejang Lebong and they only contained questions and exercises, without being equipped with the presentation of teaching material, character values and illustrative examples. This study aims to develop teaching materials in the form of illustrative Student Worksheets (LKS) containing character education in mathematics learning for grade 1 in the 2020/2021 academic year. This research was a type of development research with a 4D model (Define, Design, Develop and Disseminate). This research was conducted at SDN 01 Rejang Lebong. The subjects of this study were 16 students of class 1A. Data collection techniques in this study were: (1) observation, (2) interview, and (3) questionnaire. The data analysis technique was carried out using descriptive analysis with validation tests from 2 material experts and 1 media expert. The result of this research was the development of illustrative student worksheets (LKS) with character education in mathematics learning in grade 1 SDN 01 Rejang Lebong which produces a precontent section with a main title page (cover), an identity page, an introduction, and a table of contents. The content section contains mathematics learning material on whole numbers. The closing section of the content contains a bibliography and author profile, with a total of 20 pages using A4 paper for the contents of Student Worksheets (LKS). The results of the feasibility assessment by material experts get an average score with a score of 4.15 which is in the right category. As well as the average number of scores with 4.2 from the media design experts getting an average number of scores with an average score in the right category.
\end{abstract}

AR-RIAYAH : Jurnal Pendidikan Dasar vol. 4, no. 2, 2020

IAIN Curup - Bengkulu l p ISSN 2580-362X; e ISSN 2580-3611

http://journal.iaincurup.ac.id/index.php/JPD

DOI: $10.29240 /$ jpd.v4i2.2013 | p. $189-202$ 
Keywords: Illustrative Students Worksheets (LKS), character education in mathematics learning, Research And Development $(\mathrm{R} \& \mathrm{D})$.

\begin{abstract}
Abstrak: Penelitian ini dilatarbelakangi oleh fenomena dalam proses pendidikan yang mana bahan ajar yang digunakan belum optimal sehingga diperlukannya suatu pengembangan yang mana bahan ajar tersebut adalah Lembar Kerja Siswa (LKS) yang digunakan di SDN 01 Rejang Lebong merupakan Lembar Kerja Siswa (LKS) yang hanya memuat soal-soal latihan, tanpa dilengkapi dengan penyajian materi ajar, nilai-nilai karakter serta contohcontoh bergambar atau ilustratif. Penelitian ini bertujuan untuk mengembangkan bahan ajar berupa Lembar Kerja Siswa (LKS) ilustratif bermuatan pendidikan karakter pada pembelajaran matematika kelas 1 tahun pelajaran 2020/2021. Penelitian ini merupakan jenis penelitian pengembangan (Research and Development) dengan model 4D (Define, Design, Develop dan Disseminate). Penelitian ini dilaksanakan di SDN 01 Rejang Lebong. Subjek penelitian ini adalah siswa kelas $1 \mathrm{~A}$ dengan jumlah 16 orang. Teknik pengumpulan data pada penelitian ini menggunakan : (1) observasi. (2) wawancara. (3) angket. Teknik analisis data yang dilakukan menggunakan analisis deskriptif dengan uji validasi dari ahli materi yang terdiri dari 2 orang, ahli media 1 orang. Hasil penelitian ini adalah pengembangan Lembar Kerja Siswa (LKS) ilustratif bermuatan pendidikan karakter pada pembelajaran matematika kelas 1 SDN 01 Rejang Lebong menghasilkan bagian pra isi terdapat halaman judul utama (cover), halaman identitas, kata pengantar, daftar isi. Bagian isi terdapat materi pembelajaran matematika pada materi bilangan cacah. Bagian penutup isi terdapat daftar pustaka dan profil penulis, dengan jumlah keseluruhan 20 halaman dengan menggunakan kertas A4 untuk isi Lembar Kerja Siswa (LKS). Hasil penilaian kelayakan oleh ahli materi mendapatkan jumlah rata-rata skor dengan skor 4,15 yang termasuk kategori tepat. Serta jumlah ratarata skor dengan 4,2 dari ahli desain media mendapatkan jumlah rata-rata skor dengan rerata skor yang termasuk kategori tepat.
\end{abstract}

Kata Kunci: Lembar Kerja Siswa (LKS) ilustratif, Pendidikan Karakter Pada Pembelajaran Matematika, Penelitian Research And Development (R\&D). 


\section{PENDAHULUAN}

Pendidikan mempunyai peranan penting dalam meningkatkan dan mengembangkan kualitas sumber daya manusia baik didalam hal pengetahuan dan keterampilan. Manusia terdidik memiliki kemampuan berpikir kritis, kreatif, ungul dan memiliki nilai tambah yang baik. Melalui pendidikan, manusia dapat mengembangkan potensi yang dimiliki guna mencapai tujuan hidup yang diinginkan.

Seperti yang tercantum dalam Peraturan Pemerintah Nomor 17 Tahun 2010 tentang Pengelolaan Penyelengaraan Pendidikan Pasal 17 Ayat (3) menyebutkan bahwa "Pendidikan dasar, termasuk sekolah bertujuan membangun landasan bagi berkembangnya potensi peserta didik agar menjadi manusia yang: Beriman dan bertakwa kepada Tuhan Yang Maha Esa, Berakhlak mulia, Berilmu, Cakap, Kritis, Kreatif, dan Inovatif dan Bertanggung jawab. ."

Berdasarkan hal tersebut, dapat dijelaskan bahwasannya tujuan dari pendidikan di setiap jenjang pendidikan berkaitan erat dengan pembentukan karakter peserta didik. Tujuan tersebut dapat dioperasionalkan menjadi tujuan dari pembelajaran di sekolah melalui mata pelajaran yang diberikan oleh pendidik ${ }^{2}$. Salah satu mata pelajaran yang diberikan di sekolah yaitu matematika. Matematika merupakan pelajaran pokok yang diajarkan pada setiap jenjang pendidikan, mulai dari sekolah dasar sampai perguruan tinggi sekalipun.

Depdiknas menyatakan bahwa: "Mata pelajaran matematika perlu diberikan kepada semua siswa mulai dari Sekolah Dasar hingga Perguruan Tinggi untuk membekali siswa dengan kemampuan berpikir logis, analitis, kritis, sistematis, kreatif dan kerja sama. ${ }^{3 "}$ Dalam proses pembelajaran matematika tidak hanya dipandang sebagai ilmu yang mementingkan kemampuan kognitif saja, tetapi juga berkaitan dengan pendidikan karakter. Sehingga, dalam belajar matematika diharapkan dapat mengembangkan karakter yang baik dalam diri peserta didik.

"Menurut Ryan dan Bohin berpendapat bahwa karakter yang baik adalah tentang mengetahui apa yang baik, mencintai yang baik, dan melakukan apa yang baik. Namun pada keyataannya harapan tersebut tidak sesuai dengan keadan yang terjadi. Karakter-karakter yang baik tersebut seharusnya terdapat dalam bahan ajar yang digunakan dalam proses pembelajaran."

${ }^{1}$ Undang-Undang Republik Indonesia 2003, Undang-undang Republik Indonesia Nomor 17 Tabun 2010 tentang Pengelolan Penyelengaraan Pendidikan Pasal 17 Ayat (3). Jakarta: Pemerintah Republik Indonesia.

${ }^{2}$ Fathurrohman. Pengembangan Pendidikan Karakter, (Bandung:Refika Aditama,2017). h. 4.

${ }^{3}$ Farafatana, Pengembangan Matematika dengan Metode Preview. (Jakarta: Jurnal Teori dan Aplikasi Matematika, 2019), h. 6.

${ }^{4}$ Nuhamara, Pengutamaan Dimensi Karakter dalam Pendidikan. (Bandung:Jurnal Jaffray, 2018),h.16. 
Bahan ajar yang dikembangkan adalah Lembar Kerja Siswa (LKS). "Menurut Prastowo Lembar Kerja Siswa (LKS) merupakan bahan ajar cetak berupa lembar kertas-kertas yang berisi materi, ringkasan dan petunjuk-petunjuk pelaksanaan tugas pembelajaran yang harus dikerjakan oleh siswa yang mengacu pada kompetensi dasar yang harus dicapai". ${ }^{5}$

Sedangkan, Menurut "Tritanto Lembar Kerja Siswa (LKS) yaitu suatu panduan pembelajaran yang digunakan untuk belajar yang berisikan materi, ringkasan, dan tugas-tugas yang harus dikerjakan oleh siswa atau peserta didik" Penggunaan Lembar Kerja Siswa (LKS) bertujuan mempermudah peserta didik untuk berinteraksi dengan materi yang diberikan, sehingga peserta didik dapat melatih kemandiriannya dalam proses belajar. Tugas-tugas yang diberikan dapat disajikan dalam Lembar Kerja Siswa (LKS) yang dapat meningkatkan penguasaan peserta didik dalam materi yang diberikan, serta dapat mempermudah pendidik dalam memberikan tugas-tugas kepada siswa atau peserta didik.

Lembar Kerja Siswa (LKS) yang digunakan oleh guru di SDN 01 Rejang Lebong merupakan Lembar Kerja Siswa (LKS) yang hanya memuat soal-soal latihan berkelompok, tanpa dilengkapi dengan penyajian materi ajar, serta contohcontoh bergambar atau ilustratif. Lembar Kerja Siswa (LKS) tersebut juga belum memuat pendidikan karakter yang berilustratif. Oleh karenanya, diperlukan pengembangan Lembar Kerja Siswa (LKS) Ilustratif berbasis pendidikan karakter dengan penyajian materi ajar yang sistematis dilengkapi dengan gambar-gambar yang juga berilustratif Sehingga dapat mempermudah guru dalam menyampaikan materi ajar dengan baik dan dapat mendorong siswa secara aktif dalam memahami dan menguasai materi yang disampaikan, serta dapat memacu siswa untuk mengembangkan karakter yang baik dalam dirinya.

"Menurut Soedarso Lembar Kerja Siswa (LKS) perlu adanya daya tarik dalam perancangan buku yang mana salah satunya adalah gambar ilustratif yang mana akan membantu pembaca untuk berimajinasi sewaktu membaca sebuah buku. Gambar ilustraif merupakan gambar yang menceritakan atau memberikan penjelasan pada materi yang termuat dalam buku tersebut ${ }^{7}$."

Padahal Lembar Kerja Siswa (LKS) bukan hanya sekedar alat bantu didalam proses pembelajaran, tetapi Lembar Kerja Siswa (LKS) juga dapat menjadi pemicu dalam penemuan suatu konsep. Berdasarkan hasil pra penelitian di SDN 01 Rejang Lebong diperoleh hasil Lembar Kerja Siswa (LKS) yang digunakan saat ini hanya berfungsi sebagai salah satu penunjang proses pembelajaran saja, tidak ada pertanyaan-pertanyaan yang melatih peserta didik penanaman nilai karakternya dan dari hasil wawancara dengan wali kelas 1 tepatnya beliau

\footnotetext{
${ }^{5}$ Riskawati, Pengembangan Lembar Kerja Siswa (LKS). (Tebo: CV Pratama,2018),h. 111

${ }^{6}$ Kharunisa, Pengembangan Lembar Kerja Siswa (LKS) Bermuatan Sikap,(Jakarta: Rineka Grup, 2016),h .284.

${ }^{7}$ Ibid..,.h.299.
} 
mengatakan bahwa "Lembar Kerja Siswa (LKS) hanya berfungsi sebagai tambahan pelajaran, dan Lembar Kerja Siswa (LKS) yang digunakan itu tidak dibuat oleh guru yang bersangkutan melainkan peserta didik di anjurkan untuk membeli langsung di toko buku.". Sehingga terjadi kesenjangan terhadap hasil belajar yang kurang maksimal karena peserta didik tidak memahami soal-soal yang ada pada Lembar Kerja Siswa (LKS) tersebut. Selain itu peserta didik juga tidak bisa menghubungkan antara materi apabila dibantu dengan sejumlah media atau sarana dan prasarana yang mendukung proses interaksi yang sedang dilaksanakan akan berjalan dengan baik.

Dan juga peneliti mengambil mata pelajaran matematika karena seperti yang kita ketahui bahwasannya dalam pembelajaran matematika itu pembelajaran menggunakan angka-angka atau bilangan padahal perlu diketahui pembelajaran matematika juga terdapat karakter didalamnya sehingga dalam proses pembelajaran kita harus menggali karakter tersebut. Karakter yang digunakan dalam penelitian ini adalah pertama, karaker rasa ingin tahu yang mana dalam pembelajaran matematika akan mengakibatkan seseorang terus belajar dalam sepanjang hidupnya, terus berupaya menggali informasi-informasi terkait lingkungan disekitarnya, sehingga menjadikannya kaya akan wawasan dan ilmu pengetahuan. Rasa ingin tahu membuat seseorang mampu menelaah keterkaitan dan mampu menyelesaikan masalah dengan baik. kedua, karakter disiplin dapat terbentuk dalam mempelajari matematika, karena dalam pembelajaran matematika peserta didik diharapkan mampu mengenali suatu keteraturan pola, memahami aturan-aturan dan konsep-konsep yang teah disepakati. Adapun nilai karakter yang diharapkan mampu bekerja secara teratur dan tetib dalam menggunakan aturan-aturan dan konsep. Ketiga, karakter jujur berdasarkan pengamatan walaupun pada tahap-tahap awal terdapat contoh-contoh khusus dan ilustrasi geometris diperlukan, tetapi untuk generalisasi harus berdasarkan pembuktian deduktif. Karakter yang dapat membentuk jiwa seseorang, bahwa seseorang tidak akan mudah percaya pada isu-isu yang tidak jelas sebelum adanya pembuktian, keperibadian yang terbentuk diharapkan seseorang yang selalu dapat dipercaya dalam perkataan, tindakan dan pekerjaan.

Peneliti menggambil karakter rasa ingin tahu, disiplin dan jujur karena karakter tersebut sangat penting untuk dikembangkan untuk peserta didik khususnya peserta didik mulai dari sekolah dasar pada kelas satu yang mana dengan diterapkannya karakter tersebut dapat mengubah kebiasaan atau pola pikir peseta didik sejak dini. Dan peneliti mengambil materi bilangan cacah pada kelas satu juga karena sesuai dengan pokok bahasan yang sangat cocok dalam penelitian ini karena pada materi bilangan cacah khususnya terdapat banyak nilai-nilai karakter yang harus kita kembangkan.

${ }^{8}$ Sri S.Pd, wawancara wali kelas $1 A,(04$ desember 2019); 08.30 wib. 


\section{A. Lembar Kerja Siswa Ilustratif}

Kata yang terdapat didalam Lembar Kerja Siswa (LKS) terdiri dari tiga bagian, Lembar (Sheet), Kerja (Work) dan Siswa (Student). Dalam kamus bahasa Indonesia, kata lembar mempunyai arti helai, kerja mempunyai arti melakukan kegiatan, dan siswa mempunyai arti murid atau pelajar dari tingkat sekolah dasar sampai pada tingkat sekolah menengah atas. Jadi dapat dikatakan bahwa Lembar Kerja Siswa berarti helai bagi siswa untuk melakukan kegiatan. ${ }^{9}$

Ilustratif merupakan bahasa latin "Iilustrate", yang berarti menerangi atau menghias. Kata ilustratif yang bersumber dari bahasa latin ini dapat pula berarti penghias atau pendukung dalam suatu proses pemahaman terhadap suatu pandangan atau objek, ilustratif merupakan suatu gambar yang dapat menghiasi serta dapat membantu suatu konsep pemahaman terhadap objek ${ }^{10}$. Menurut Tity Soegiarty "Kata ilustratif dapat pula diartikan atau digunakan dalam seni yaitu seni musik atau seni rupa yang berarti yang dapat memberikan keindahan dan memberikan sesuatu pemahaman tentang objek" "11.

Menurut Sartiah Lembar Kerja Siswa (LKS) Ilustratif yaitu suatu bahan ajar cetak berupa lembaran-lembaran kertas yang berisikan suatu materi, rangkuman atau ringkasan, gambar-gambar serta petunjuk dalam pengerjaan tugas pembelajaran yang mana harus dikerjakan oleh peserta didik dan mengacu pada salah satu kompetensi dasar yang mana kompetensi itu harus dicapai peserta didik. ${ }^{12}$

\section{B. Pendidikan Karakter}

Karakter adalah watak, tabiat, akhlak, adab, atau ciri kepribadaian seseorang yang terbentuk dari hasil internalisasi berbagai nilai kebajikan (virtules) yang diyakini dan digunakan sebagai landasan berpikir, bersikap dan bertindak. ${ }^{13}$ Karakter dapat dimaknai sebagai cara berpikir dan berperilaku yang khas tiap individu untuk hidup dab bekerja sama, baik dalam lingkup keluarga, masyarakat, bangsa dan Negara. Kata karakter diartikan sebagai perilaku yang tampak dalam kehidupan sehari-hari baik dalam bersikap maupun dalam bertindak. Menurut Scerenco mengatakan bahwa karakter adalah sebagai atribut atau ciri-ciri yang membentuk dan membedakan ciri pribadi, ciri etis, dan kompleksitas mental dari seseorang, suaaatu kelompok atau bangsa. ${ }^{14}$

\footnotetext{
${ }^{9}$ M.arifin, Pengantar Lembar Kerja Siswa,(Semarang: PT Pratama,2009),h.12

${ }^{10}$ Maman Tocharman, Pendidikan Seni Rupa, ( Bandung: Upi Press, 2006), h. 199

${ }^{11}$ Ibid.., h. 199

${ }^{12}$ Sartiah, Pengembangan Lembar Kerja Siswa Ilustratif, (Semarang: Unnes Education Journal Universitas Negeri Semarang, ISSN. 2252-6935, 2015), h. 55.

${ }^{13}$ Ardy Wiyani, Praktek \& Strategi Membumikan Pendidikan Karakter Di SD.

14 Muclas Samani dan Harianto, Konsep Dan Model Pendidikan Karakter,(Bandung: PT
} Remaja Rosdakarya, 2013). 
Pendidikan karakter pada intinya bertujuan untuk membentuk bangsa yang tangguh, kompetitif, berakhlak mulia, bermoral, bertoleran, bergotong royong, berjiwa patriotik, berorientasi ilmu pengetahuan dan teknologi yang semuanya dijiwai oleh iman dan takwa kepada Tuhan Yang Maha Esa berdasarkan Pancasila.

\section{Pembelajaran Matematika}

Sebagai suatu bidang ilmu yang merupakan alat berpikir, berkomunikasi, memecahkan permasalahan yang ada dengan mudah, yang menggunakan unsur-unsurnya berpikir kritis, analisis danbersifat membangun, generalitas dan individualistas, serta mempunyai cabang-cabang antara lain aritmatika, aljabar, geometri dan analisis pandangan ini adalah pengertian matematika menutut pendapat Sri. ${ }^{15}$

Sedangkan ilmu tentang logika mengenai bentuk, susunan, besaran, dan konsep-konsep yang berhubungan satu sama lainnya dengan jumlah yang banyak yang terbagi dalam tiga bidang, yaitu aljabar, analisis, dan geometri disebut dengan matermatika. Adapun untuk pengertian Pembelajaran matematika merupakan suatu proses atau kegiatan guru mata pelajaran matematika dalam mengajarkan matematika kepada para peserta didik dalam upaya pendidik untuk menciptakan suasana dan pelayanan terhadap kemampuan, potensi, minat, bakat, dan kebutuhan siswa tentang matematika yang amat beragam agar terjadi interaksi optimal antara pendidik kepada peserta didik ataupun peserta didik dengan yang lainnya dalam mempelajari matematika ${ }^{16 .}$

\section{Pendidikan Karakter Pada Pembelajaran Matematika}

Terdapat beberapa nilai-nilai karakter dalam proses pembelajaran matematika berdasarkan Permendiknas nomor 22 tahun 2006 tentang Standar Isi mata pada Pelajaran Matematika yang didalamnya terdapat 7 (tujuh) tujuan nilai-nilai yang terkadnung didalam mata pelajaran matematika maka ada beberapa nilai karakter yang dapat dikembangkan melalui pembelajaran matematika diantaranya sebagai berikut: ${ }^{17}$

\section{Disiplin}

Karakter disiplin ini dapat terbentuk dalam mempelajari matematika, karena dalam matematika peserta didik diharapkan mampu mengenali suatu keteraturan pola, memahami aturan-aturan dan konsep-konsep yang telah

\footnotetext{
${ }^{15}$ Juhartutik, Sri. Pendidikan Matematika Dalam Pembelajaran. (Semarang:Pedididikan Matematika Unes .2012).

${ }^{16}$ Sri Anitah W. Strategi Pembelajaran Matematika, (Jakarta: Universitas Terbuka, 2008), Cetakan 3, h. 74.

${ }^{17}$ Permendinas, Undang-undang Republik. Indonesia nomor 22 tabun 2006 tentang standar isi pembelajaran matematika.(Jakarta: Pemerintahan Republik Indonesia, 2003).
} 
disepakati. Nilai karakter yang diharapkan dalam belajar matematika adalah seseorang diharapkan mampu bekerja secara teratur dan tertib dalam menggunakan aturan-aturan dan konsep-konsep. Dalam matematika konsep-konsep tersebut tidak boleh dilanggar karena dapat menimbulkan salah arti.

\section{Jujur}

Matematika tidak menerima generalisasi berdasarkan pengamatan (induktif) walaupun pada tahap-tahap awal contoh-contoh khusus dan ilustrasi geometris diperlukan, tetapi untuk generalisasi harus berdasarkan pembuktian deduktif. Suatu kejujuran sangat penting dalam pembelajaran matematika ini karakter jujur yang dapat membentuk jiwa seseorang, bahwa seseorang tidak akan mudah percaya pada isu-isu yang tidak jelas sebelum ada pembuktian. Kepribadian yang terbentuk diharapkan adalah seseorang yang selalu dapat dipercaya dalam perkataan, tindakan dan pekerjaannya, karena selalu dapat menunjukkan pembuktian dari setiap perkataan dan tindakannya.

\section{Kerja Keras}

Karakter yang ingin dibentuk adalah tidak mudah putus asa. Belajar matematika, seseorang harus teliti, tekun dan telaten, dalam memahami yang tersirat dan tersurat. Ada kalanya seseorang keliru dalam pengerjaan suatu perhitungan, namun belum mencapai hasil yang benar, maka seseorang diharapkan dapat dengan sabar melihat kembali (looking back) apa yang telah dikerjakan secara runtut dengan teliti, tidak mudah menyerah terus berjuang untuk menghasilkan suatu jawaban yang benar.

\section{Kreatif}

Seseorang yang belajar matematika akan terbiasa untuk kreatif dalam menyelesaikan persoalan yang dihadapinya. Dalam menyelesaikan persoalan ada yang dapat menyelesaikan dengan cara yang panjang, namun ada pula yang mampu mengerjakan dengan singkat. Bila seseorang terbiasa menyelesaikan permasalahan matematika, maka orang tersebut akan terbiasa memunculkan ide yang kreatif yang dapat membantunya menjalani kehidupan secara lebih efektif dan efisien.

\section{Rasa Ingin Tahu}

Memunculkan rasa ingin tahu dalam matematika akan mengakibatkan seseorang terus belajar dalam sepanjang hidupnya, terus berupaya menggali informasi-informasi terkait lingkungan di sekitarnya, sehingga menjadikannya kaya akan wawasan dan ilmu pengetahuan. Rasa ingin tahu membuat seseorang mampu menelaah keterkaitan, perbedaan dan analogi, 
sehingga diharapkan mampu menjadi a good problems solver (mampu menyelesaikan masalah dengan baik).

\section{Mandiri}

Dalam pelajaran matematika kita senantiasa menghadapi tantangan, berbagai permasalahan yang menuntut kita untuk menemukan solusi atau penyelesaiannya. Untuk itu peserta didik harus mampu memiliki sikap yang tidak mudah bergantung pada orang lain, namun berupaya secara mandiri untuk menyelesaikan tugas-tugas yang dihadapi dengan baik.

\section{Tanggung Jawab}

Kebiasaan disiplin dalam bernalar yang terbentuk dalam mempelajari matematika melahirkan suatu sikap tanggung jawab atas pelaksanaan kewajiban yang seharusnya dilakukan, baik tanggung jawab terhadap diri sendiri, masyarakat, negara dan Tuhan Yang Maha Esa. ${ }^{18}$

Dapat saya simpulkan bahwa karakter yang akan dicapai oleh peserta didik dalam penelitian saya ini adalah karakter rasa ingin tahu, disiplin dan jujur. Yang mana dari karakter rasa ingin tahu yang besar terhadap soal yang diberikan peserta didik tentunya akan mencari tahu permasalah yang ada pada soal tersebut, karakter disiplin yang mana siswa-siswi dalam pengerjaan tugas yang ada harus sesuai dengan waktu yang telah ditentukan dan terus menerus menggali informasi yang terkait pada soal tersebut dengan begitu peserta didik akan lebih banyak menemukan jawabannya dan karakter jujur sangat diperlukan agar dapat membentuk karakter sesorang.

\section{METODE PENELITIAN}

Jenis Penelitian yang digunakan peneliti ini menggunakan metode penelitian dan pengembagan atau sering disebut dengan (Reseach and development) penelitian pengembangan (R\&D) adalah tahapan yang digunakan untuk mengembangkan dan memvalidasi produk. Langkah dari penelitian ini mempunyai beberapa proses biasanya bisa disebut dengan (Reseach and development). ${ }^{19}$

Tujuan dari penelitian pengembangan adalah terciptanya sebuah produk baik hasil penyempurnaan ataupun yang baru merupakan tujuan yang diharapkan dari penelitian pengembangan. Menurut Gay dkk. menjelaskan bahwa tujuan penelitian pengembangan untuk mengembangkan produk yang efektif yang digunakan dalam membantu kualitas pembelajaran dan penelitian tersebut bukan untuk menguji teori, tujuan penelitian yang melakukan pengembangan ini adalah

${ }^{18}$ Said Hamid Hassan, dkk,Pengembangan Pendidikan Budaya dan Karakter Bangsa, Baban Pelatiban Penguatan Metodeologi Pembelajaran Nilai-nilai Budaya untuk. Membentuk. Daya Saing dan Karakter Bangsa, (Jakarta: Puskur Balitbang Kemendiknass, 2010), h. 8

${ }^{19}$ Sugiyono. Metode Penelitian Pendidikan.( Bandung: Alfabeta: 2012).h. 407 
untuk menghasilkan suatu produk yang dianggap penting dan menunjukkan kepentingan yang layak dihasilkan serta diselenggarakan. ${ }^{20}$

Adapun model pengembangan yang akan direncanakan dalam penelitian ini mengikuti alur dari Sivasaliman Thiagarajan, model pengembangan 4-D tahap utama Define, Design, Develop, dan Disseminste atau diadaptasikan menjadi model 4$\mathrm{P}$, yaitu pendefinisian, perancangan, pengembangan dan penyebaran. Penerapan langkah utama dalam penelitian ini tidak hanya menurut versi asli tetapi disesuaikan dengan karekteristik subjek dan tempat yang akan dilakukan penelitian.

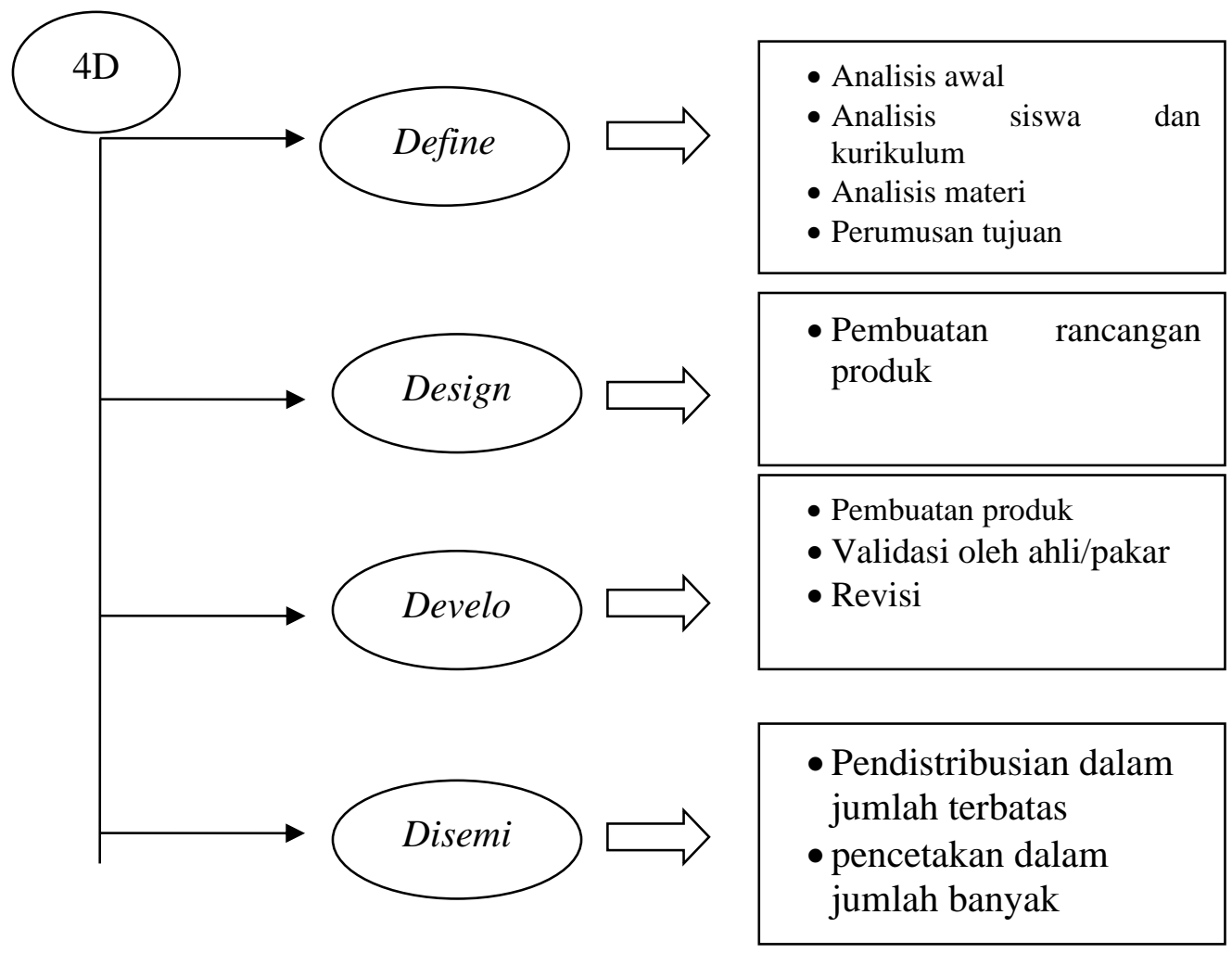

Gambar 1.1 : Prosedur R\&D Model 4D. ${ }^{21}$

${ }^{20}$ Endang, Mulyatiningsih, Metode Penelitian Terapan Bidang Pendidikan, (Bandung: Alfabeta, 2013)

${ }^{21}$ Thiagarajan, Instructional Development For Training Of Exceptional Children : A Sourcebook, ( Washington, D.C: National Center Improvement Of Education Systems, 1974), h. 15. 


\section{HASIL DAN PEMBAHASAN}

Tujuan penelitian ini yaitu mengembangkan bahan ajar berupa Lembar Kerja Siswa (LKS) ilustratif bermuatan pendidikan karakter pada pembelajaran matematika.

\section{A. Deskripsi Produk}

Lembar Kerja Siswa (LKS) ini dilengkapi dengan bagian pendahuluan (Halaman judul, Kata pengantar, Daftar isi dan petunjuk penggunaan), bagian isi (Materi pokok, Lembar Kerja Siswa ilustratif bermutan pendidikan karakter, Petunjuk kerja, Tugas dan evaluasi), dan bagian penutup (Daftar pustaka dan profil penulis). Lembar Kerja Siswa (LKS) ilustratif bermuatan pendidikan karakter pada pembelajaran matematika ini dimaksudkan untuk mengembangkan pengetahuan karakter siswa kelas 1 SDN 01 Rejang Lebong dalam memahami materi tentang bilangan cacah.

Langkah awal didalam pembuatan produk ini berupa Lembar Kerja Siswa (LKS) ilustratif bermuatan pendidikan karakter pada pembelajaran matematika ini adalah menganalisis kebutuhan siswa dan guru terlebih dahulu selanjutnya membuat sebuah rangcangan atau desain dengan menentukan materi yang akan digunakan, selanjutnya mencari gambar yang sesuai kemudian dilakukannya penyusunan produk dengan menerapkan konsep teoritis yang diuraikan dalam BAB II. Secara umum, langkah-langkah yang dilakukan adalah pengumpulan materi dan bahan yang diperlukan dalam Lembar Kerja Siswa (LKS) ilustratif bermuatan pendidikan karakter pada pembelajaran matematika. Produk atau draf ini dibuat dengan menggunakan Microsoft Word dan Fhotoshoop. Setelah melalui proses pendefinisian, perancangan, proses pengembangan dan dihasilkan produk awal yaitu Lembar Kerja Siswa (LKS) ilustratif bermuatan pendidikan karakter pada pembelajaran matematika.

\section{B. Data Validasi Produk}

Validasi dilakukan oleh tiga orang ahli yaitu satu orang ahli desain media dan dua orang ahli materi dan penelitian ini menggunakan jenis penelitian Research and Develoment (R\&D). Penelitian ini bertujuan untuk menghasilkan produk baru melalui proses pengembangan. Model penelitian dan pengembangan produk (Research and Develoment) yang digunakan peneliti dalam penelitiannya adalah model 4D sebagai berikut:

1. Tahap Pendifinisian (Define)

2. Tahap Perancangan (Design)

3. Tahap Pengembangan (Develop)

4. Tahap Penyebaran (Disiminate) 


\section{Kajian Produk Akhir}

Produk bahan ajar berupa Lembar Kerja Siswa (LKS) ilustratif bermuatan pendidikan karakter yang membahas mengenai mata pelajaran matematika pada tema pengalaman masa kecil yang mengandung materi bilangan cacah untuk siswa kelas 1 SDN 01 Rejang Lebong telah dibuat melalui serangkaian penelitian dan pengembangan. Produk ini juga telah melalui tahap validasi produk yang melibatkan ahli materi, ahli media, dan praktisi pembelajaran matematika atau guru matematika di sekolah. Setelah melalui tahap validasi, produk bahan ajar Lembar Kerja Siswa (LKS) ilustratif bermuatan pendidikan karakter pada pembelajaran matematika. Hasil dari validasi tersebut digunakan untuk memperoleh penilaian kualitas produk serta saran dan komentar untuk melakukan revisi terhadap produk yang dikembangkan.

Berdasarkan hasil penelitian oleh 2 orang ahli materi, 1 orang ahli media dan produk Lembar Kerja Siswa (LKS) Ilustratif bermuatan pendidikan karaakter yang dikembangkan ini memiliki kualitas yang "Tepat”. Oleh karena itu, bahan ajar Lembar Kerja Siswa (LKS) ilustratif bermuatan pendidikan karakter pada pembelajaran matematika yang dapat digunakan secara mandiri khususnya bagi siswa kelas 1 SDN 01 Rejang Lebong.

Berikut ini keunggulan yang dimiliki Lembar Kerja Siswa (LKS) ilustratif bermuatan pendidikan karakter pada pembelajaran matematika :

1. Lembar Kerja Siswa (LKS) ilustratif bermuatan pendidikan karakter pada pembelajaran matematika memuat materi bilangan cacah yang ringkas, jelas, dan mudah dipahami oleh siswa.

2. Produk yang dikembangkan sistematis dan berisi petunjuk yang jelas sehingga siswa dapat memahami maksud dan tujuan dari materi yang disajikan.

3. Lembar Kerja Siswa (LKS) ilustratif bermuatan pendidikan karakter pada pembelajaran matematika ini dapat digunakan untuk pembelajaran secara individu maupun kelompok secara mandiri di luar kelas atau di rumah.

4. Produk yang dikembangkan ini dapat mempermudah guru dalam proses pembelajaran.

\section{KESIMPULAN}

Hasil penelitian ini dengan judul Pengembangan Lembar Kerja Sisa (LKS) Ilustratif Bermuatan Pendidikan Karakter Pada Pembelajaran Matematika yang mana dari penelitian ini menghasilkan suatu produk bahan ajar berupa Lembar Kerja Siswa (LKS) yang layak digunakan dan dapat meningkatkan kualitas dalam proses pembelajaran materi tentang bilangan cacah. Penelitian tersebut telah melalui tahap analisis kebutuhan siswa dan guru serta tahap validasi oleh ahli materi, ahli media, dan guru. 
Kelayakan bahan ajar berupa Lembar Kerja Siswa (LKS) dari berbagai tahapan-tahapan yang telah dilalui adalah sebgai berikut ini:

1. Pendefinisian produk bahan ajar yang didapat dari analisis kebutuhan baik itu dari siswa maupun guru bahan ajar sangat harus dikembangkan.

2. Perancangan atau desain produk dilakuakan agar terciptanya bahan ajar yang layak digunakan.

3. Penilian produk berupa Lembar Kerja Siswa (LKS) ilustratif bermuatan pendidikan karakter pada pembelajaran matematika oleh ahli materi tahap 1 menunjukkan bahwa kualitas bahan ajar dari aspek keseluruhan termasuk dalam kategori "Tepat" dengan skor rata-rata 4,2.

4. Penilian produk berupa Lembar Kerja Siswa (LKS) ilustratif bermuatan pendidikan karakter pada pembelajaran matematika oleh ahli materi tahap 2 menunjukkan bahwa kualitas bahan ajar dari aspek keseluruhan termasuk dalam kategori "Tepat" dengan skor rata-rata 4,1.

5. Penilian produk berupa Lembar Kerja Siswa (LKS) ilustratif bermuatan pendidikan karakter pada pembelajaran matematika oleh ahli desain tahap menunjukkan bahwa kualitas bahan ajar dari aspek keseluruhan termasuk dalam kategori "Tepat" dengan skor rata-rata 4,2.

\section{DAFTAR PUSTAKA}

Arifin M., Pengantar Lembar Kerja Siswa, Semarang: PT Pratama,2009.

Endang, Mulyatiningsih, Metode Penelitian Terapan Bidang Pendidikan, Bandung: Alfabeta, 2013.

Farafatana, Pengembangan Matematika dengan Metode Preview. Jakarta: Jurnal Teori dan Aplikasi Matematika, 2019.

Fathurrohman. Pengembangan Pendidikan Karakter, Bandung: Refika Aditama, 2017.

Harianto, Muclas Samani, Konsep Dan Model Pendidikan Karakter,Bandung: PT Remaja Rosdakarya, 2013.

Juhartutik, Sri. Pendidikan Matematika Dalam Pembelajaran. Semarang: Pedididikan Matematika Unes .2012.

Kharunisa, Pengembangan Lembar Kerja Siswa (LKS) Bermuatan Sikap, Jakarta: Rineka Grup, 2016.

Nuhamara, Pengutamaan Dimensi Karakter dalam Pendidikan. Bandung: Jurnal Jaffray, 2018

PermendiKnas, Undang-undang Republik Indonesia nomor 22 tahun 2006 tentang standar isi pembelajaran matematika. Jakarta: Pemerintahan Republik Indonesia. 2003.

Riskawati, Pengembangan Lembar Kerja Siswa (LKS). Tebo: CV Pratama, 2018. 
Sartiah, Pengembangan Lembar Kerja Siswa Ilustratif, Semarang: Unnes Education Journal Universitas Negri Semarang, ISSN. 2252-6935, 2015.

Sri Anitah W. Strategi Pembelajaran Matematika, Jakarta: Universitas Terbuka, 2008.

Sugiyono, Metode Penelitian Pendidikan Pendekatan Kuantitatif, Kualitatif, dan R\&D, Bandung: Alfabeta,2010.

Sugiyono. Metode Penelitian Pendidikan. Bandung: Alfabeta: 2012.

Thiagarajan, Instructional Development For Training Of Exceptional Children : A Sourcebook, Washington, D.C: National Center Improvement Of Education Systems, 1974.

Tocharman Maman, Pendidikan Seni Rupa, Bandung: Upi Press, 2006.

Undang-Undang Republik Indonesia, Undang-undang Republik Indonesia Nomor 17 Tabun 2010 tentang Pengelolan Penyelengaraan Pendidikan Pasal 17 Ayat (3). Jakarta: Pemerintah Republik Indonesia. 2003.

Wiyani Ardy, Praktek \& Strategi Membumikan Pendidikan Karakter Di SD Jogyakarta: Ar-Ruzz Media, 2013. 